\title{
Pengaruh Pengalaman Praktik Kerja Industri, Pelaksanaan Bimbingan Kejuruan dan Dukungan Keluarga terhadap Kesiapan Kerja Siswa SMK Swasta di Kabupaten Bantul
}

\author{
Ria Setyawati \\ Jurusan Perhotelan, Politeknik Negeri Balikpapan, Balikpapan \\ ria.setyawati@poltekba.ac.id
}

\begin{abstract}
This study aims at finding: the work readiness of the students of private vocational high schools in Bantul Regency and the effect of job training program, implementation of vocational guidance, and the family support both individually and together on the work readiness of the students of private vocational high schools in Bantul Regency. This study was ex-post facto research using the quantitative approach. The subject was the students of private vocational high schools in Bantul Regency. A sample of 256 students was established by using the proportional random sampling technique. The data were collected using a questionnaire in Likert Scale of 4 options. The questionnaire was tested for its validity and reliability before it was used to gather the data. The data were analyzed by using the descriptive statistic and double regression by using three independent variables and one dependent variable.This research showes five findings. First, the work readiness of the students of privat vocational high schools in Bantul Regency is in a low category (61\%). Second, the job training program has asignificant effect on the students'work readiness. Third, the implementation of vocational guidance does not have a significant effect on the students' work readiness. Fourth family support does not have a significant effect on the students' work readiness. Fifth, the job training program, vocational guidance, and family support simultaneously contribute only $28.7 \%$ to the work readiness of students of private vocational high schools in at Bantul Regency.
\end{abstract}

Keywords:the work readiness, the job training program, vocational guidance, family supports

\begin{abstract}
Abstrak
Penelitian ini bertujuan untuk mengungkapkan kesiapan kerja siswa SMK Swasta di Kabupaten Bantul dan pengaruh pengalaman praktik kerja industri, pelaksanaan bimbingan kejuruan, dan dukungan keluarga baik secara sendiri-sendiri maupun secara bersama-sama terhadap kesiapan kerja siswa di Kabupaten Bantul. Penelitian ini merupakan penelitian ex-post facto dengan pendekatan kuantitatif. Subjek penelitian adalah siswa SMK Swasta di Kabupaten Bantul.Sampel sebanyak 256 siswa ditentukan menggunakan teknik proportional random sampling. Teknik Pengumpulan data menggunakan angket dengan model skala likert 4 alternatif jawaban.Validitas dan reliabilitas angket sebelum digunakan untuk mengambil data penelitian. Analisis data dilakukan dengan statistik deskriptif dan analisis regresi ganda dengan tiga variabel bebas dan satu variabel terikat. Penelitian ini menghasilkan lima temuan. Pertama, kesiapan kerja siswa SMK swasta di Kabupaten Bantul sebanyak $61 \%$ termasuk kategori rendah. Kedua, pengalaman praktik kerja industri berpengaruh secara signifikan terhadap kesiapan kerja siswa. Ketiga, pelaksanaan bimbingan kejuruan tidak berpengaruh secara signifikan terhadap kesiapan kerja siswa. Keempat, dukungan keluarga tidak berpengaruh secara signifikan terhadap kesiapan kerja sisawa. Kelima, secara simultan pengalaman praktik kerja industri, pelaksanaan bimbingan kejuruan, dan dukungan keluarga hanya berkontribusi 28,7\% terhadap kesiapan kerja siswa SMK swasta di Kabupaten Bantul.
\end{abstract}

Kata kunci:kesiapan kerja, praktik kerja industri, bimbingan kejuruan, dukungan keluarga

\section{Pendahuluan}

Permasalahan pendidikan di Indonesia adalah masih rendahnya mutu pendidikan.Keberadaaan SMK dalam mempersiapkan tenaga kerja tingkat menengah yang terampil masih perlu ditingkatkan.Belum semua lulusan SMK dapat memenuhi tuntutan lapangan kerja sesuai dengan kompetensinya.Hal ini karena adanya kesenjangan antara 
keterampilan yang dimiliki oleh lulusan

SMK dengan keterampilan, peserta didik SMK belum sepenuhnya memiliki kesiapankerja, karena masih banyak lulusan SMK yang masih menganggur.

Sedangkan permasalahan bidang ketenagakerjaan saat ini antara lain: kualitas SDM dan produktifitas tenaga kerja yang relatif masih rendah, sedikitnya lowongan kerja, sehingga mengakibatkan banyaknya pengangguran. Hal tersebut menjadi persoalan yang harus diselesaikan pemerintah melalui menyiapkan tenaga kerja yang siap pakai, dalam arti bisa langsung kerja di dunia usaha dan industri.

Kesenjangan yang terjadi antara sekolah dengan industri menjadikan lingkungan kerja yang berbeda. Lingkungan kerja adalah salah satu faktor yang menentukan kesiapan kerja. Siswa akan merasa puas jika lingkungan kerjanya mendukung dan menyenangkan. Lingkungan yang aman, nyaman, bersih dan fasilitas yang lengkap akan membuat siswa merasa senang dan melakukan pekerjaan sehingga pada akhirnya dapat menimbulkan semangat untuk kerja sehingga siswa akan siap untuk bekerja.

Pendidikan kejuruan ditinjau secara sistem menurut Evans \& Edwin (1978: 24) merupakan bagian dari sistem pendidikan yang mempersiapkan individu dalam suatu pekerjaan atau kelompok pekerjaan. Hal tersebut sependapat dengan Fich and Crunkilton (1999: 75), "The mayor goal vocational is to prepare students for successful employment in the labor market" yang berarti tujuan utama pembelajaran kejuruan adalah untuk mempersiapkan siswa menjadi pekerja yang sukses di dunia kerja.

Menurut Clarke \& Winch (2007:9) pendidikan kejuruan dikhususkan untuk menyiapkan seseorang untuk bekerja, dan proses pekerjaan menekankan pada aspek yang bersifat praktis dan teknis. Wenrich et.al (1988:5) menyatakan bahwa pendidikan kejuruan adalah pendidikan khusus yang dirancang untuk mempersiapkan siswa memasuki lapangan kerja tertentu atau meningkatkan mutu pekerjaan yang dikerjakannya.

\subsection{Kesiapan Kerja}

Kesiapan kerja menurut kamus besar bahasa Indonesia (2005: 554) "kerja diartikan sebagai kegiatan untuk melakukan sesuatu yang dilakukan atau diperbuat dan sesuatu yang dilakukan untuk mencari nafkah, mata pencaharian. Sependapat dengan Moh. Thayeb (1998: 27) "Kerja diartikan sebagai suatu kelompok aktivitas, tugas, atau kewajiban yang sama dan dibayar, yang memerlukan atribut-atribut yang sama dalam suatu organisasi tertentu". Menurut M. Brammer dan L. Shostromm (1982:121) menyatakan bahwa "Readiness for learning is a well-known education concept. Children, for instance, are not "Ready" to read until they have achieved a certain level of motivation, maturation, and 
basic skill development" yang maknanya bahwa kesiapan dalam belajar akan tercapai bila siswa telah mencapai tingkat motivasi tertentu, kematangan dan berkembangnya kemampuan dasar.

\subsection{Pengalaman Praktik Kerja Industri}

Pengalaman menurut Chalpin (2006:176) "Pengalaman adalah pengetahuan atau ketrampilan yang diperoleh dalam praktik atau dari luar usaha belajar". Pengalaman merupakan pengetahuan atau keterampilan yang diketahui dan dikuasai seseorang sebagai akibat dari perbuatan atau pekerjaan yang telah dilakukan sebelumnya selama jangka waktu tertentu. Menurut Dalyono (2005:167), pengalaman dapat mempengaruhi fisiologi perkembangan individu yang merupakan salah satu prinsip perkembangan kesiapan (readiness) siswa SMK dalam mempersiapkan diri memasuki dunia kerja.Pengalaman merupakan pengetahuan atau ketrampilan yang sudah diketahui dan dikuasai seseorang, sebagai akibat dari perbuatan atau pekerjaan yang telah dilakukan sebelumnya selama jangka waktu tertentu.

Program penyelenggaraan praktik kerja industri merupakan langkah nyata untuk membuat sistem pendidikan dan pelatihan kejuruan lebih relevan dengan dunia kerja untuk menghasilkan tamatan yang bermutu. Praktik kerja industri merupakan program wajib yang harus diselenggarakan oleh Sekolah Menengah
Kejuruan yang wajib diikuti oleh siswa.Upaya pelaksanaan praktik kerja industri dimaksudkan supaya siswa belajar secara mental dan ketrampilan nantinya siap bekerja di industri.

Praktik kerja industri merupakan implementasi dari kebijakan link and match yang berwawasan sumber daya manusia, masa depan, mutu, keunggulan, profesionalisme, nilai tambah dan efisiensi bagi pelaku pendidikan kejuruan. Kebijakan link and match diharapkan mampu merubah pendekatan supply driven menjadi demand driven dengan melibatkan dunia usaha atau dunia industri dalam perencanaan, pelaksanaan, dan evaluasi pendidikan kejuruan. Kebijakan tersebut bertujuan agar dapat memperhatikan kecenderungan pasar kerja, sehingga para siswa dapat memiliki ketrampilan dasar yang bermanfaat untuk meraih kesempatan berkarier. (Masriam Bukit, 2002: 529).

\subsection{Pelaksanaan Bimbingan Kejuruan}

Korth menerangkan (1973: 55-56) bahwa bimbingan "... is seen as the provision of a milieu in which experiences relating to pupil self-understanding and the understanding of one's own world are afforded".Sependapat dengan Nana Syaodih Sukmadinata (2007: 7), dimana bimbingan merupakan suatu bidang dan program pendidikan untuk membantu mengoptimalkan perkembangan siswa dalam hal menyesuaikan diri dengan situasi 
yang dihadapi dan perencanaan masa depan.

Menurut Prayitno (1999: 63)

Pelayanan bimbingan dan konseling di sekolah meliputi empat bidang pelayanan yang harus diberikan kepada siswa yaitu bimbingan pribadi, bimbingan sosial, bimbingan belajar dan bimbingan kejuruan. Pada bidang pelayanan bimbingan kejuruan meliputi: (a) pemantapan pemahaman diri berkenaan dengan kecenderungan karir yang hendak dikembangkan, pemantapan orientasi dan informasi karir, (c) orientasi dan informasi pada dunia kerja dan usaha untuk memperoleh penghasilan untuk memenuhi kebutuhan hidup, (d) orientasi dan informasi terhadap pendidikan yang lebih tinggi khususnya sesuai dengan karir yang dikembangkan.

Pelaksanaan bimbingan kejuruan lebih menitik beratkan kepada layanan yang mengarah untuk persiapan dalam bekerja. Melalui layanan bimbingan kejuruan sebagai suatu proses diharapkan mampu menciptakan sikap kemandirian siswa dalam menentukan arah pilih pekerjaan yang sesuai dengan kemampuannya. Bimbingan yang diberikan kepada siswa bertujuan untuk membantu siswa menentukan arah kecenderungan yang perlu dikembangkan, dengan cara memberikan orientasi dan informasi tentang /kerja.

\subsection{Dukungan Keluarga}

Dalyono (2010:129), menyatakan bahwa lingkungan dapat dibagi menjadi tiga bagian antara lain: (1) lingkungan alam atau luar ialah segala sesuatu yang ada di dunia selain manusia seperti rumah, tumbuhan, air, hewan, dan iklim; (2) lingkungan dalam segala sesuatu yang mencakup lingkungan alam atau luar; (3) lingkungan sosial masyarakat adalah semua orang atau manusia lain yang mempengaruhi kita seperti keluarga, teman, sekolah, lebih lanjut secara fisiologis lingkungan meliputi segala kondisi dan material jasmaniah dalam tubuh manusia seperti gizi, air, nutrisi, vitamin, system syaraf, peredaran darah, system pencernaan, pernafasan, sel pertumbuhan dan kesehatan jasmani.

Menurut sosiolog Goodge dalam Berns (2004:102) menyatakan bahwa keluarga itu bukan hanya individu, yang memiliki peringkat dalam struktur kelas masyarakat, dan sebuah gambaran yang memberikan pengaruh macrosystem pada perkembangan anak dan status sosial keluarga membantu menentukan peluang individu untuk pendidikan dan pekerjaan, serta untuk interaksi sosial. Lingkungan keluarga merupakan suatu tempat dimana anak berinteraksi sosial dengan orang tua yang paling lama.Keluarga merupakan lembaga pendidikan utama yang berada di luar sekolah yang memberikan andil utama dan mendasar di dalam pembentukan sikap dan kepribadian. 


\section{Metode Penelitian}

Penelitian ini merupakan penelitian ex-post facto. Penelitian dilakukan di 7 SMK swasta dengan kriteria akreditasi jurusan A di kabupaten Bantul pada siswa kelas XII dengan jumlah populasi sebanyak 1035 siswa. Teknik sampling yang digunakan adalah "propotional random sampling".Variabel penelitian ini terdiri dari 3 (tiga) variabel bebas dan 1 (satu) variabel terikat.variabel bebas dalam penelitian ini adalah pengalaman praktik kerja industri, pelaksanaan bimbingan kejuruan dan dukungan keluarga. Sedangkan variabel terikat yang akan dipengaruhi adalah kesiapan kerja siswa SMK swasta.

Pada uji hipotesis, pengaruh variabel-variabel bebas terhadap variabel terikat di uji dengan regresi ganda. Perhitungan untuk mengetahui pengaruh dari tiap variabel bebas terhadap variabel terikat dengan menggunakan regresi berganda. Uji hipotesis dilakukan dengan menggunakan bantuan paket program SPSS. Pengaujian hipoteis dilakukan dengan menggunakan teknik regresi berganda. Sebagai kriteria penerimaan dan penolakan digunakan signifikan $5 \%$ jika $\mathrm{p}<0,05$ maka $\mathrm{H}_{\mathrm{o}}$ ditolak.

\section{Hasil Penelitian}


rendah $=\mathrm{X} \geq \mathrm{M}+1,5 \mathrm{SD}$, Rendah $=\mathrm{M} \leq \mathrm{X}$ $<\mathrm{M}-1,5 \mathrm{SD}$, Tinggi $=\mathrm{M}-1,5 \mathrm{SD} \leq \mathrm{X}<$ Mi, dan Sangat tinggi $=\mathrm{X}<\mathrm{M}-1,5 \mathrm{SD}$. Hasil tersebut dibuat tabel distribusi yang dikategorisasikan kedalam bentu persentase seperti yang terlihat pada gambar 2, diketahui Berdasarkan persentase distribusi kategorisasi variabel kesiapan kerja sebanyak 156 siswa (61\%) dengan kategori rendah.

Berdasarkan hasil penelitian secara keseluruan menunjukkan bahwa kesiapan kerja siswa SMK dipengaruhi oleh pengalaman praktik kerja industri, pelaksanaan bimbingan kejuruan dan dukungan keluarga.Dalam penelitian ini ditemukan bahwa, kesiapan kerja siswa SMK swasta di Kabupaten Bantul menunjukkan kecenderungan yang masih kurang baik. Hal ini dapat diketahui dari 256 orang siswa sebagai sampel responden, hanya 14 siswa $(5,4 \%)$ siswa yang memiliki kategori sangat tinggi dan terdapat 156 siswa $(61 \%)$ dengan kategori rendah. Hal tersebut menunjukkan keadaan siswa SMK swasta di Kabupaten Bantul bahwa belum siap untuk bekerja.Sehingga belum tercapainya tujuan dari pendidikan kejuruan di SMK yang dikhususkan untuk menyiapkan siswa memasuki dunia kerja.

Kondisi kesiapan siswa saat ini belum mencapai tingkatan atau keadaan dalam proses perkembangan secara mental, sosial dan emosional untuk melakukan kegiatan. Padahal kesiapan secara mental dibutuhkan untuk menghadapi perubahan dalam hidupnya nanti.

\section{(b) Variabel Pengalaman Praktik Kerja} Industri

Berdasarkan data variabel pengalaman praktik kerja industri, diperoleh nilai maksimal 49 dan skor nilai minimal 16.nilai mean 30,2383, median 31,0000 , std.deviation 6,45116 seperti yang terdapat pada tabel distribusi frekuensi variabel pengalaman praktik kerja industri.

Tabel; 2 : Distribusi Frekuensi Variabel Pengalaman Praktik Kerja Industri

\begin{tabular}{cccc}
\hline No. & Interval & F & Percent \\
\hline 1. & $46,4-50,1$ & 1 & $0,4 \%$ \\
2. & $42,6-46,3$ & 6 & $2,3 \%$ \\
3. & $38,8-42,5$ & 19 & $7,4 \%$ \\
4. & $35-38,7$ & 42 & $16,4 \%$ \\
5. & $31,2-34,9$ & 48 & $18,7 \%$ \\
6. & $27,4-31,1$ & 51 & $20 \%$ \\
7. & $23,6-27,3$ & 48 & $18,7 \%$ \\
8. & $19,8-23,5$ & 28 & $11 \%$ \\
9. & $16-19,7$ & 13 & $5,1 \%$ \\
& Jumlah & 256 & $100 \%$
\end{tabular}

Penentuan kecenderungan variabel pengalaman praktik kerja industri, setelah nilai minimum dan nilai maksimum diketahui, maka selanjutnya mencari nilai rata-rata ideal $(\mathrm{Mi})$ dengan rumus $\mathrm{Mi}=1 / 2$ $(\mathrm{Xmak}+\mathrm{Xmin})$, mencari standar deviasi (SDi) dengan rumus $\mathrm{SDi}=1 / 6$ (Xmak Xmin). Berdasarkan acuan norma diatas, mean ideal variabel pengalaman praktik kerja industri adalah 40. Standar deviasi ideal adalah 8. Dari perhitungan di atas dapat dikategorikan dalam 4 kelas sebagai berikut:Sangat rendah $=X \geq M+1,5 S D$, 
Rendah $=\mathrm{M} \leq \mathrm{X}<\mathrm{M}-1,5 \mathrm{SD}$,

Tinggi $=\mathrm{M}-1,5 \mathrm{SD} \leq \mathrm{X}<\mathrm{Mi}$, Sangat tinggi $=\mathrm{X}<\mathrm{M}-1,5 \mathrm{SD}$. Berdasarkan perhitungan tersebut dapat diketahui melalui presentase distribusi seperti yang terlihat pada gambaer 2, dimana kategorisasi variabel pengalaman praktik kerja industri sebanyak 102 siswa (40\%) dengan kategori rendah.

Hasil diatas menunjukan adanya praktik kerja industri siswa dapat belajar untuk berpartisipasi secara langsung di industri yang relevan dengan kompetensi yang dimiliki siswa.

Pengalaman praktik kerja siswa SMK swasta di Kabupaten Bantul dalam kategori rendah. Berdasarkan penelitian menyatakan bahwa pengalaman praktik kerja industri paling banyak berkategori rendah sebanyak 102 siswa (40\%) dan paling sedikit berkategori sangat rendah sebanyak 48 siswa (18\%). Sehingga dapat disimpulkan bahwa pengalaman praktik kerja industri yang dimiliki oleh siswa SMK swasta di Kabupaten Bantul masih rendah sebanyak $40 \%$. Hal tersebut menunjukkan bahwa belum sepenuhnya siswa dapat menerapkan apa yang telah mereka dapat selama di sekolah.

Berdasarkan hasil uji hipotesis menunjukkan bahwa pengalaman praktik kerja industri berpengaruh secara signifikan dan merupakan variabel yang paling dominan berpengaruh terhadap kesiapan kerja siswa SMK Swasta di Kabupaten Bantul.

\section{(c) Variabel Pelaksanaan Bimbingan Kejuruan}

Berdasarkan data variabel pelaksanaan bimbingan kejuruan, diperoleh nilai maksimal sebesar 46 dan nilai minimal 12, nilai mean 24,6094, median 24,0000, std.deviation 6,34280. Seperti yang terlihat pada tabel 3 berikut ini :

Tabel 3 Distribusi frekuensi variabel pelaksanaanbimbingan kejuruan.

\begin{tabular}{cccc}
\hline No. & Interval & F & Percent \\
\hline 1. & $43,2-47$ & 5 & $2 \%$ \\
2. & $39,3-43,1$ & 1 & $0,4 \%$ \\
3. & $35,4-39,2$ & 6 & $2,3 \%$ \\
4. & $31,5-35,3$ & 19 & $7,4 \%$ \\
5. & $27,6-31,4$ & 42 & $16,4 \%$ \\
6. & $23,7-27,5$ & 72 & $28,1 \%$ \\
7. & $19,8-23,6$ & 59 & $23 \%$ \\
8. & $15,9-19,7$ & 33 & $13 \%$ \\
9. & $12-15,8$ & 19 & $7,4 \%$ \\
& Jumlah & 256 & $100 \%$ \\
\hline
\end{tabular}

Penentuan kecenderungan variabel pelaksanaan bimbingan kejuruan, setelah nilai minimum dan nilai maksimum diketahui, maka selanjutnya mencari nilai rata-rata ideal $(\mathrm{Mi})$ dengan rumus $\mathrm{Mi}=1 / 2$ $($ Xmak + Xmin $)$, mencari standar deviasi (SDi) dengan rumus SDi $=1 / 6(\mathrm{Xmak}-$ Xmin). Berdasarkan acuan norma diatas, mean ideal variabel pelaksanaan bimbingan kejuruan adalah 30. Standar deviasi ideal adalah 6. Dari perhitungan di atas dapat dikategorikan dalam 4 kelas sebagai berikut: Sangat rendah $=X \geq M+1,5 S D$, Rendah $=\mathrm{M} \leq \mathrm{X}<\mathrm{M}-1,5 \mathrm{SD}$, Tinggi $=\mathrm{M}$ 
JURNAL SOSIAL HUMANIORA DAN PENDIDIKAN VOL. 2 NO. 1

$-1,5 \mathrm{SD} \leq \mathrm{X}<\mathrm{Mi}$, Sangat tinggi $=\mathrm{X}<\mathrm{M}$

- 1,5 SD. Hasil ini dapat dilihat pada

Berdasarkan perhitungan tersebut dapat diketahui melalui presentase distribusi seperti yang terlihat pada gambar 3, dimana presentase distribusi kategorisasi variabel pelaksanaan bimbingan kejuruan sebanyak 99 siswa (39\%) dengan kategori sangat rendah.

Hasil penelitian diatas menunjukan bahwa pelaksanaan bimbingan kejuruan paling banyak berkategori sangat rendah sebanyak 99 siswa (39\%) dan paling sedikit berkategori tinggi sebanyak 35 siswa (13\%). Berdasarkan hasil uji hipotesis menunjukkan bahwa pelaksanaan bimbingan kejuruan tidak signifikan terhadap kesiapan kerja siswa SMK Swasta di Kabupaten Bantul.

\section{(d) Variabel Dukungan Keluarga}

Berdasarkan data variabel dukungan keluarga, diperoleh skor tertinggi sebesar 53 dan skor terendah 16, nilai mean 38,4219 , median 30,0000 std.deviation 6,61443 . Seperti yang terdapa pada tabel 4 berikut ini :

Tabel 4. Distribusi Frekuensi Variabel Dukungan Keluarga

\begin{tabular}{lccc}
\hline No. & Interval & F & Percent \\
\hline 1. & $49,6-53,7$ & 1 & 0,4 \\
2. & $45,4-49,5$ & 7 & $2,7 \%$ \\
3. & $41,2-45,3$ & 3 & $1,2 \%$ \\
4. & $37-41,1$ & 38 & $15 \%$ \\
5. & $32,8-36,9$ & 49 & $19 \%$ \\
6. & $28,6-32,7$ & 47 & $18,4 \%$ \\
7. & $24,4-28,5$ & 58 & $23 \%$
\end{tabular}

$\begin{array}{cccc}8 . & 20,2-24,3 & 35 & 14 \% \\ 9 . & 16-20,1 & 16 & 6,3 \% \\ & \text { Jumlah } & 256 & 100 \%\end{array}$

Penentuan kecenderungan variabel dukungan keluarga, setelah nilai minimum dan nilai maksimum diketahui, maka selanjutnya mencari nilai rata-rata ideal (Mi) dengan rumus $\mathrm{Mi}=1 / 2(\mathrm{Xmak}+$ Xmin), mencari standar deviasi (SDi) dengan rumus $\mathrm{SDi}=1 / 6(\mathrm{Xmak}-\mathrm{Xmin})$. Berdasarkan acuan norma diatas, mean ideal variabel dukungan keluarga adalah 37,5. Standar deviasi ideal adalah 7,5. Dari perhitungan di atas dapat dikategorikan dalam 4 kelas sebagai berikut: Sangat rendah $=\mathrm{X} \geq \mathrm{M}+1,5 \mathrm{SD}$, Rendah $=\mathrm{M} \leq$ $\mathrm{X}<\mathrm{M}-1,5 \mathrm{SD}$, Tinggi $=\mathrm{M}-1,5 \mathrm{SD} \leq \mathrm{X}$ $<\mathrm{Mi}$, Sangat tinggi $=\mathrm{X}<\mathrm{M}-1,5 \mathrm{SD}$.

Berdasarkan perhitungan tersebut dapat diketahui melalui presentase distribusi seperti yang terlihat pada gambar 4, dimana persentase distribusi kategorisasi variabel dukungan keluarga sebanyak 95 siswa (37\%) dengan kategori rendah.

Hasil penelitian menunjukkan bahwa dukungan keluarga paling banyak berkategori sangat rendah sebnayak 95 siswa $(37,1 \%)$ dan paling sedikit berkategori sangat tinggi sebanyak 36 siswa $(14,1 \%)$. Selanjutnya berdasarkan hasil uji hipotesis menunjukkan bahwa dukungan keluarga berpengaruh secara signifikan terhadap kesiapan kerja siswa SMK Swasta di Kabupaten Bantul. Hal ini dapat dilihat dari hasil analisis korelasi yang diperoleh 
dari nilai $\mathrm{r}$ sebesar 0,351 pada $\mathrm{p}<0,05$, yang berarti bahwa hubungan variabel dukungan keluarga tidak signifikan terhadap kesiapan kerja siswa SMK.

\subsection{Pengaruh pengalaman praktik kerja} industri, pelaksanaan bimbingan kejuruan dan dukungan keluarga terhadap kesiapan kerja siswa SMK swasta di Kabupaten Bantul

Berdasarkan hasil pengujian hipotesis hanya variabel pengalaman praktik kerja industri yang berpengaruh secara signifikan terhadap kesiapan kerja siswa SMK swasta di Kabupaten Bantul.Sedangkan variabel pelaksanaan bimbingan kejuruan dan dukungan keluarga tidak berpengaruh secara signifikan terhadap kesiapan kerja siswa SMK swasta di Kabupaten Bantul. Berdasarkan hasil penelitian kesiapan kerja dari 256 siswa, paling banyak berkategori sangat rendah sebanyak 156 siswa (61\%) dan paling sedikit berkategori tinggi sebanyak siswa $(4,6 \%)$. Hal ini menunjukkan bahwa kesiapan kerja siswa masih sangat rendah. Selain itu hasil uji hipotesis secara simultan dengan koefisien determinasi atau besarnya kontribusi pengalaman praktik kerja industri (X1), pelaksanaan bimbingan kejuruan (X2) dan dukungan keluarga (X3) terhadap kesiapan kerja siswa (Y) adalah 0,287 atau $28,7 \%$.

Berdasarkan hasil analisis secara bersama-sama pengaruh pengalaman praktik kerja insudtri, pelaksanaan bimbingan kejuruan dan dukungan keluarga memberikan kontribusi terhadap kesiapan kerja siswa.Pada dasarnya praktik kerja industri memberikan kesempatan bagi siswa untuk melatih ketrampilan sesuai dengan bidang keahliannya dan menjembatani penyiapan siswa untuk terjun ke dunia industri setelah menempuh pendidikan di sekolahnya. Dengan adanya pelaksanaan bimbingan kejuruan, siswa akan memiliki gambaran tentang jenis-jenis pekerjaan serta kemungkinan-kemungkinan yang akan terjadi dengan pekerjaan tersebut. Sedangkan dukungan keluarga memberikan rasa nyaman, rasa percaya diri dan lebih dapat menyesuaikan diri dengan baik.

Hasil analisis dari besarnya kontribusi variabel bebas secara bersamasama terhadap variabel terikat membuktikan bahwa kombinasi variabel pengalaman praktik kerja industri, pelaksanaan bimbingan kejuruan dan dukungan keluarga berkontribusi sebesar 28,7\% terhadap kesiapan kerja siswa SMK swasta di Kabupaten Bantul. Dengan demikian masih ada faktor lain sebesar 71,3\% belum dapat dijelaskan berasal dari variabel lain yang dapat mempengaruhi kesiapan kerja siswa SMK swasta di Kabupaten Bantul.

\section{Kesimpulan}

Berdasarkan hasil penelitian dapat diambil kesimpulan bahwa tingkat kesiapan kerja siswa SMK swasta di Kabupaten 
Bantul dikategorikan rendah. Hal ini memberikan implikasi bahwa kesiapan kerja siswa SMK swasta di Kabupaten Bantul masih sangat perlu dibina dan ditingkatkan, sehingga siswa memiliki pengetahuan, ketrampilan, tanggung jawab, sikap kerja yang baik untuk dapat langsung bekerja setelah tamat SMK. Ini terlihat pada 4 variabel yakni kesiapan kerja siswa SMK swasta di Kabupaten Bantul sebanyak 61\% siswa termasuk kategori rendah; Pada kategori pengalaman praktik kerja industri berpengaruh secara signifikan terhadap kesiapan kerja siswa SMK swasta di Kabupaten Bantul; Variabel pelaksanaan bimbingan kejuruan tidak berpengaruh terhadap kesiapan kerja siswa SMK swasta di Kabupaten Bantul; Untuk dukungan keluarga tidak berpengaruh terhadap kesiapan kerja siswa SMK swasta di Kabupaten Bantul. Selanjtunya pengalaman praktik kerja industri, pelaksanaan bimbingan kejuruan dan dukungan keluarga secara bersama-sama hanya berkontribusi sebesar $28,7 \%$ terhadap kesiapan kerja siswa SMK swasta di Kabupaten Bantul.

\section{Saran}

Harus adanya kerja sama salah satunya dengan komunikasi yang baik antara industri dan sekolahan guna memantau perkembangan praktik kerja siswa, jadi tidak hanya satu kali monitoring dalam satu periode praktik kerja di industri tetapi bisa 3 atau 4 kali monitoring; Perlu ditambahkannya jam pratik kerja di industri, sehingga ssiswa lebih banyak praktik di industri yang akan menambah pengalaman kerja siswa.

\section{Daftar Pustaka}

Chaplin,J.P(2006).KamusLengkapPsikologi.(Te rjemahanKartiniKartono). Jakarta: PT. Raja GrafindoPersada. (Bukuasliditerbitkantahun 1989).

Clarke, L, \& Winch, C (2007).Vocational Education: International Approaches, Development and System. Routledge Taylor \& Prancis Group, London

Dalyono.(2005). Psikologi Pendidikan. Jakarta: Rineka Cipta.

Evans, R. N. \& Edwin, L. H. (1978).Foundation of vocational education.Columbus: Charles E. Merrill Publishing Company.

Finch, Curtis R, and Crunkilton, John R. (1999).Curriculum Development in Vocational and Technical Education: Planning, Conten, and Implemntation (5thed.). Boston: Allyn and Bacon

Korth. J. A. (1973). Counseling Psycology And Guidance; an Overview In Out Line :Charles C. Thomas Publisher.

Lawrence M, Brammer and Everett L. Shostrom. (1982). Therapeautic Psychology.Fudamentals of Counseling and Psychohotherapy.Englewood Cliffs.Prentice- Hall,INC.

Masriam Bukit. (2002). Beberapa Masalah Dalam Implementasi Pendidikan Sistem Ganda Di SMK. Jakarta: Depdiknas.

Prayitno.(1999).

PelayananBimbingandanKonseling

SMU, Buku Bab III. Jakarta. PenebarSwadaya. 